UDC 32.001:94

Will POGHOSYAN

\title{
THE SHY STALINISM
}

\begin{abstract}
The current mode of life in Russia combines the features of desperately daring steps in geopolitical domain with an amazing shyness of thought when facing the tiniest changes in theoretical constructs.

Today, crowds of laymen, officials and many "learned" dignitaries in the West and in the East face the need to reject the prejudices concocted using dirty data techniques. The time has come to release Stalin from the Nazi captivity and to reinstate his Membership within the Great Triplett of Roosevelt Stalin - Churchill. The call for serious changes in the theoretical constructs has become a vital demand for the survival of mankind. Both the West and Russia have to act urgently. Periculum in mora.

As of today, having been brought to bay, the correct estimation of the genuinely large merits by Stalin before Motherland and Humanity is popping up irresistibly, as if it were a moth piercing through the pupa, dumping as a useless shell the prejudices like "Stalin equals Hitler". This concerns primarily the evolution of the shy Stalinism by Putin. The time has come to update the judgments on Stalin at the governmental level. The bigotry by Brzezinski is to be terminated. The Destiny of Russia is at stake.
\end{abstract}

Keywords: Shy Stalinism, Roosevelt, Stalin, Churchill, Putin, war hawks, prejudices, war of information, Liberal Communists, timocracy.

The current mode of life in Russia combines the features of desperately daring steps in geopolitical domain with an amazing shyness of thought when facing the tiniest changes in theoretical constructs. The resolute measures on repatriating the Crimea to Russia and extraordinary energy in the country's defense go hand in hand with a bashful rejection of commonplace truths thrusted upon the world by the American Hawks. Their aim is to demolish the state from the inside while unleashing aggression against Russia from the outside.

Prior to Khrushchev's contriving the personality cult of his deceased Sovereign, Stalin, alongside with Roosevelt and Churchill, was recognized both in the West and in the East as a personality on the scale of world history. Courtesy of Khrushchev, Both Brzezinski and the American Hawks have post factum equalized the imaginary cult of Stalin to the genuine cult of Hitler. Today, the prejudices like "Stalin equals Hitler", "Stalinism is Totalitarism", "The USSR is an evil empire" threaten the survival of the human kind. (Poghosyan 2014)

Today, crowds of laymen, officials and many "learned" dignitaries in the West and in the East face the need to reject the prejudices concocted using dirty data techniques. The time has come to release Stalin from the Nazi captivity and to reinstate his Membership within the Great Triplett of Roosevelt - 
Stalin - Churchill. The call for serious changes in the theoretical constructs has become a vital demand for the survival of mankind. Both the West and Russia have to act urgently. Periculum in mora.

Suppression of Stalin's merits inflicts considerable damage upon Russia. Cui bono? The Liberal Communists, i.e., betrayers of the proletarian thought, who had abruptly defected to their class enemies by the late 1991. How to stay sane in it? The Liberal Communists are neurotics. It is common knowledge that the neurotic upstarts will always overdo it with the genuinely liberal sentiments. Not unlike savages, the neurotics taboo the words and names that remind them of their former ideals bred into them since their infancy.

According to Vladimir Putin, the problem is that if you say something positive about Stalin, someone will be displeased, and if you say something negative, again someone will be displeased. As we see, the problem is reduced to evaluating the grand total of Stalin's rule. It is needed to understand the interior connection of the positive and the negative in Stalin's rule, to identify the principle linking the one to the other, and to find out the overbalance. Will the positive side outweigh, then the Stalin rule gets positive rating, if it is the other side, the rating is negative.

The statehood principle of both the USSR and the CPR is indicated by the term "Democratic Centralism", merging the two elements: democracy and despotism. The former is the objective, while the latter is the expedient. The strife for civilization and democracy is the positive side of Stalin Rule, while the despotism is negative. The will for democracy is a permanent, while the despotism is a provisional element of Democratic Centralism. As soon as the goal is achieved, and democracy takes routes, the despotism will die out. The internal link between democracy and despotism was made up as early as at the time of antiquity. As noted by Hegel, "it was necessary, after Solon had given the Athenians free democratic laws, that Pisistratus seize power, so as leaning on it to teach the Athenians to obey those laws." And only after that obedience had taken routs, the supremacy of the Pisistratides became superfluous."

Thus, which side of Stalin's activities overweighs: striving for civilization and democracy or the despotism? To provide a correct answer to this question, it is sufficient to make a comparison between Stalin's contribution to the crushing defeat of Nazi Germany and his share of guilt for the repressions of 1927. There is no doubt that in the comparison of those two outstanding manifestations of the positive and the negative the contribution by Stalin into the Great Victory will overweigh. The victory in the Great Patriotic War will explain (with no vindication) the repressions of 1937 aimed at preparing the Nation to the upcoming war. Thus, the activities by Stalin are integrally evaluated as positive.

The American hawk-agitators keep digging into the pre-war archival documents all along, hunting for new evidence of connections between the USSR and the Third Reich. In their biased opinion, the negative activities by Stalin overweigh. The correct unbiased evaluation of the political figure impersonating the principle of Democratic Centralism, will bring together both the adversaries and adherents of Stalin who judge him more with political passions than with scholarly reasoning.

Historically, Democratic Centralism has been added up as the principle of the Great Revolutions of the West: the English, the American and the French. It has been adopted by the Bolsheviks. However, in contrast to the independents, the American Patriots and the Jacobins, they had committed two, rather 
than one, revolutions: the sociopolitical one and the cultural. As noted by Lenin, "our political and social turnover preceded the cultural turnover, the cultural revolution that we are all facing now". In France, the Cultural Revolution went under the name of "The Age of Enlightenment". In the USSR, the Cultural Revolution prompted to retain the revolutionary despotism. It was needed to boost civilization and to train the population in using books and trading in the European fashion. The Cultural Revolution was instrumental in establishing a state-of-the-art system of education. Then, one decade later, a direct threat ripened to the very existence of the Soviet Union on the part of Nazi Germany. Under that situation, renunciation of despotism as promoter of democracy would have to wait.

Thus, the balance of Stalin Rule cannot be regarded as unfavorable for the country that he ruled. There were repressions, but they cannot be inculpated to Stalin personally. Successful actions by Hitler and Franco incited rumors and gossip in Moscow about plots, treasons and "the fifth column". Popular discontent was going over the top. In 1937, the country was engulfed with the mania of button pushing and persecution of suspects.

Dmitry Medvedev is appalled by the idea of rehabilitating the good name of Stalin. He is convinced of the importance of barring the vindication of those who used to kill their own people. Those utterances are word-for-word reiterations of the anti-Russian superstitions. It is to be mentioned that both the Jacobins and the Bolsheviks are the true leaders of the masses. They led the way to be the first to fall. Oswald Spengler admired them. "The Jacobins were prepared to sacrifice all others because they sacrificed themselves. They fought against the majority of their compatriots and against half of Europe at the fronts. They fetched and dragged along everything. They created armies out of nothing; they fought with no officers, with no weapons". According to Spengler, "the Russian revolutionaries never put at the head of their program the cowardice before the enemy". The Russian revolutionaries, the Bolsheviks, established the courageous Socialist Republic, which in under three decades substantially contributed to the defeat of the Third Reich that had proudly pronounced itself a totalitarian state.

In the years of ruling by the defectors Gorbachev and Yeltsin, the subservient criticism of Stalinism resulted in the leaders' complete loss of the feelings of danger and civil virtue. The Soviet Union and Russia became regional states, obedient to the West. Since the time of Plato it has been known that with no definitive judgment of danger there is no courageous state. "A state can be courageous due to one of its parts, due to this part providing the state with the power to permanently retain the idea of dangers, i.e. that they have some specific features inspired by the legislator through upbringing" (Rp. IV 429 c.). The word "silovik" (strongman) ascends to the doctrine on courage by Plato. Civil courage is bred in man as prompted by the legislation inspiring him a correct idea on the dangers. As noted by Plato, man retains courage in suffering, pleasures and passions, as well as at the time of fear, renouncing it at no time. This type of man in today's Russia is most probably Vladimir Putin. He restored civil virtue to the huge country. The current leaders of Russia may be not so much in possession of political wisdom, social justice or consensus-generating prudence, but rather of inflexible courage.

This form of governance was made up in all USSR following its collapse, i.e. after the democratic centralism was broken down into its constituents. Democracy and despotism go together. Therefore, the political system of today's Russia is often called "controlled or sovereign democracy". Its precise name is 
timocracy. The vice of today's timocracy is "prikhvatization" (private appropriation) of state assets by official and private persons under the guise of the newly introduced privatization. Heading the timocratic state are Liberal Communists, people of mixed morals and manners, partly courageous, partly inclined to predatory hoarding of wealth and to extravagant luxury. If they can change their character and reverse the situation using the remnants of decency to crush the runaway corruption, then timocracy will transition into democracy. Otherwise, it will be completely distorted into a commonplace oligarchy with a democratic revolution in prospect. (Poghosyan 2011)

Putin is a leader of the Stalin's red hot tempering. He is confronting a transition from the shy imitation to the fruitful conscientious tracing of Stalin's patterns. Stalin was a skillful tutor. He impressed upon the Red Army warriors a legitimate concept of danger, injected them with an all-conquering courage, expertly appraised the sacramental and the popular character of the initiating war, stirred up the huge country using the biblical address "brothers, sisters". The Red Army warriors assaulted the enemy with a battle cry: "For Fatherland! For Stalin!", because in Stalin they saw the personification of Fatherland. The soldiers of Wehrmacht did nothing of the kind. They simply fulfilled the orders by the Führer. The Great Patriotic war involving the complete Nation, is a single iron grip, a single volition for self-sacrifice, a single sacramental wrath, a single symbol of victory. The symbol of victory was Stalin, whether or not it was in line with anyone's wishes or not.

As of today, having been brought to bay, the correct estimation of the genuinely large merits by Stalin before Motherland and Humanity is popping up irresistibly, as if it were a moth piercing through the pupa, dumping as a useless shell the prejudices like "Stalin equals Hitler". This concerns primarily the evolution of the shy Stalinism by Putin. The time has come to update the judgements on Stalin at the governmental level. The bigotry by Brzezinski is to be terminated. The Destiny of Russia is at stake.

Brzezinski is a man who is malicious, mean, entirely unscrupulous and possessed by obscurantism. He bullies the layman by what Putin called the greatest catastrophe of the $20^{\text {th }}$ century: "the disappearance of the state wherein he was a secret agent of the KGB. He wants to resuscitate the Soviet Union". Brzezinski is an agitator and a troubled person (a term by the Jacobins). He will distort facts and utterances until he can see Russia in ruins. Putin's discourse however is that under the guise of a totalitarian state denied the right to existence; they dismantled the state of Democratic Centralism. Complaints against "the evil empire" are only occasions and pretexts for the cold war unleashed by US and England against the USSR. Its genuine reason concealed itself in the rising Soviet might inciting fear and envy in the Anglo-Saxons. The US President by that time was already the cynical hawk Harry Truman. He was alien to the spirit of camaraderie and sincere collaboration of the Great Triplett Roosevelt - Stalin - Churchill. He never concealed from Stalin that the atom bombing of Japan had targeted the USSR.

In tangled arguments by Brzezinski, we have found no deep analysis. He equated Putin to Hitler (who else?), because the current leader of Russia, unlike Gorbachev or Yeltsin, did not play the yes-man to the American Hawks juggling with the fascist word "totalitarian": yes, the USSR is a totalitarian state. "Putin had been a secret agent of the KGB". What a scare! Brzezinski is far from realizing that it was there that Putin had been put together as a real and true strongman, as the holder of the fortitude that always 
retains the true and legitimate opinion of the threats to the state that is known as courage. At this point Putin stands high as a conscientious follower of Stalin's example.

At the start of the Great Patriotic War, the idea of courage had already been materialized. Which was not the case in Nazi Germany. Hitler was not a strongman in the classical sense. Of the right and legitimate opinion on danger, unlike Stalin, he had none. As to him, the principal threat to the existence of the German Nation was coming from the Jews. This wrongful and illegitimate opinion of Hitler on danger had become the proximate cause of the Jewish Holocaust. Clearly, to kill a tiny oppressed nation what is needed is extreme brutality, rather than courage. The Third Reich was a brutal, but not a courageous, state. That was why Wehrmacht was doomed since the moment of its treacherous attack on the USSR. Annihilation of his own people was done by Hitler, not Stalin. The main threat to the state, according to Stalin, was coming from the Third Reich, rather than from the own people. The deportations of the Germans, the Crimean Tartars and the Chechens, like the deportation of the Japanese in US were resettlements to alternative areas of a vast country, rather than relocations to the other world.

Events in Ukraine show the vitality of fascism. What is the stimulant of its growth? The line of Khrushchev - Brzezinski. Equating Communism to Fascism is a double-edged sword. On the one hand, it really throws a shadow upon Communism, but on the other it exalts Fascism. Why? Because a humane idea-rich doctrine is being equated to a lean racist theory. It is tantamount to the statement "two equals one". Democratic Centralism combining the two elements requires a sustainable democratic development. Meanwhile, Fascism is a total uniformity of ideas and people, their unification (Gleichschaltung), a monotonous reiteration of the same principle of implicit obedience to Führer. It is clear that equating Communism with Fascism will exalt Fascism stipulating its growth. That is not understood by the adherents of obscurantist prejudices in Russia. Thus, Alexander Tsipko has reached as far as to equate Marx to Hitler. "There is much in common between the social racism of Karl Marx who had distinguished between the full-fledged and defective (outdated) classes, and the ethnic racism by Hitler drawing a distinction between the full-fledged and defective races". (Pogosyan 2015) A conversion of Nazi No.1 into a great thinker not yielding to Marx in theory is hilarious. The social racism discovered in Marx by Tsipko is fiction. It will glorify the doctrine by Hitler making it more attractive. Here is your growth of Fascism in Ukraine; there you are the rise of Nazi spirit worldwide.

Racism is always ethnic. Instead of proliferating on the abstract "crimes of the Jacobins" and "Crimes of the Bolsheviks", the Russian political leaders and philosophers should rather comment on the specific offence committed by a conscript soldier from the Russian military base in Gyumri. On the threshold of the Centenary of the Armenian Holocaust the Russian youth ruthlessly gunned down a whole family of people and tried to escape to Turkey. On the Russian heavy-handed approach by Orjonikidze in Georgia Lenin said: "Before I was taken ill, Dzerzhinsky briefed me on the work of the Commission and on the incident, which made a viscous effect on me" With regard to Putin and Medvedev, the crime of Gyumri did not affect them at all. This is attested by their silence and by the deferred work of the investigating authorities. The Russian leaders keep a deep silence because their concept of "good Russian nationalism" had evoked the spirit of great-power chauvinism in the young generation stirring up "the sea of the Great Russian chauvinistic riffraff" (Lenin). True, after the bloodcurdling event in Armenia the Russian leaders 
effected a sharp turn from nationalism to military patriotism. Love for Home Country is an important attribute of democracy. The American Revolution started with declaring the emergence of a new nation - the Saxon Tribe. However, the newly made Americans were wise enough to name themselves patriots, rather than nationalists.

This turnabout of the front of ideological struggle in Russia, rejection of the "truly Russian disposition" (Lenin) and the transition to the patriotic upbringing of the young generation terminates the period of an amazing timidity of thought before the tiniest modifications of theoretical constructs. The time has come to cast off the shackles of obscure prejudices.

To disclaim the chief prejudices of these days, it is sufficient to use a simple and clear discourse leaning upon common sense: if Stalin had indeed been equal to Hitler, the USSR would have fought on the side of Nazi Germany. However, it was allied with the Anglo-Saxon states and fought against the Third Reich. Therefore, the prejudices of the type "Stalin equals Hitler" are sheer fabrications not worth a bean. The matter is that the American Hawk-agitators use dirty technologies to suppress everyone's thought with such a mass of prejudices, that, according to Spinoza, "not a single corner in the soul is left for common sense even for a doubt". That is why it never enters anyone's head to ask: if Stalin and Hitler are so much alike, why then they come to be at different sides of the barricades? I have many times recommended the Russian leaders to eliminate from the official political vocabulary the battle words of the American Hawks "totalitarian" and "authoritarian" aimed at demolishing Russia following the example of the USSR. Those words have been contrived by the Fascists, they can be used only to describe the Italian Fascism and the German Nazism. Brzezinski failed in his calculations. He is emanating conspiracy, or rather, obscure prejudices threatening today not only Russia, but also life on the planet Earth.

Meanwhile, Russia is losing the information war. That can be seen from the ease of the illegal antiRussian sanctions being introduced and hardening. The American hawks are as good as the medieval obscurants. They have re-established "the realm of superstitions, prejudices and delusions" (Hegel). Political knowledge at this time has become nothing but information and prejudices. "And what prejudices! The ones that transform people from intelligent beings into cattle by completely preventing each one from using one's own judgement to tell the truth from the lies" (Spinoza, "Tractatus TheologicoPoliticus". Preface). Nonetheless, the Hawks are winning on account of their false theoretical constructs being assumed to come from the great ideology of the founding fathers perceived as a philosophicpolitical program for changing the world. The Russian leaders can boast none of any similar ideology. Under the given circumstances, Russia will need an advanced ideology of sustainable democratic development, rejection of obscurantist prejudices and retention of inviable world order established by the Great Triplet at the Yalta Conference. Without advanced ideology Russia is doomed to perdition.

The timid, shy Stalinism by Putin has exhausted itself completely. He is currently doing his service to Russia with a genuinely Stalinist perseverance. On June 29, 1941, in the wake of the treacherous assault on the USSR by Nazi Germany, Stalin said: "Lenin had left us a great legacy, we, his successors - we have blown it all..." Fortunately, the great legacy has been preserved and magnified. Meanwhile, in 1991, fifty years later, in the time of peace, having been born in the USSR, we allowed our high-ranking drinking companions and their henchmen to destroy and to loot the Great Legacy left by our Fathers. And those 
scoundrels are still yelping: "Stalin equals Hitler", "the USSR is an evil empire", and so on. I have done this referencing to show, how significant it is, at the level of state governance, to put an end to the obscurant prejudices designed to destroy Russia. The talent of Putin and his comrades is needed precisely at these circumstances. They will not allow Russia to be looted and destroyed.

\section{REFERENCES}

Friedrich, Carl \& Brzezinski, Z. (1956). Totalitarian Dictatorship and Autocracy. Harvard University Press. Cambridge, Mass.

Hegel. Philosophie des Geistes, § 435.

Plato. Politeia (Der Staat).

Poghosyan, W. (2014). Antirossiiskie predrassudki Zapada - ugroza tret'ei mirovoi voiny (The Anti-Russian Prejudices in the West is the Threat of WWIII). In Golos Armenii, 11 oktyabrya 2014.

Poghosyan, W. (2011). Iz timokratii v ... ? Formy pravleniya i gosudarstvennye nravy v sovremennom mire (From Timocracy to...? The Forms of Governance and the State Habits in the Modern World). In Golos Armenii, 27 oktyabrya, 2011.

Poghosyan, W. (2015). Nezavisimaya gazeta (Independent Paper), 27.05.2015.

Spengler (1920). Preussentum und Sozialismus.

Spinoza (1862). Tractatus Theologico-Politicus. Preface. London: Trübner \& Co. 